\title{
Scrip Money and Slump Cures: Iowa's Experiments with Alternative Currency during the Great Depression
}

\author{
SARAH ELVINS
}

FOLLOWING THE WALL STREET CRASH OF 1929, Americans faced rising unemployment and the paralysis of the economy with a surprising level of stoicism. As conditions worsened and it became clear that the slump was not just a temporary setback, citizens across the country attempted to find a cure for the crisis. One solution entertained by hundreds of communities was the use of scrip, or alternative currency, to offer relief and put money in the hands of consumers. In those cities and towns, the unemployed (and in some cases municipal employees) were issued special certificates, which could only be spent at local retailers. Supporters argued that scrip would aid the jobless and stimulate new business, eventually encouraging more "real" currency to be reintroduced into circulation. Thousands embraced the use of scrip as a way for each individual to do his or her part to speed recovery.

Alternative currency schemes ultimately were not successful in ending the Great Depression. Still, those experiments reveal much about popular attitudes towards the economy prior

Research for this article was made possible by grants from the State Historical Society of Iowa, the University Research Grants Program of the University of Manitoba, and the Social Sciences and Humanities Research Council of Canada.

THE ANNALS OF IOWA 64 (Summer 2005). (C) The State Historical Society of Iowa, 2005. 
to the New Deal. The overwhelming majority of alternative currency plans were not revolutionary in nature: they harnessed the power of private consumers to improve economic conditions without posing a threat to the established capitalist order. Indeed, most boosters of scrip saw it as a temporary fix that would speed the return of the "normal" business conditions of the 1920s. Scrip also tapped into notions of civic pride and local loyalty to encourage participation. Because scrip stayed within one particular community to circulate, proponents argued that it focused recovery efforts and allowed neighbors to pull together to achieve visible results. Only after conditions "at home" improved would people turn their attention to helping those outside of the community. ${ }^{1}$

Scrip had supporters across the United States, but the state of Iowa became particularly associated with the phenomenon. ${ }^{2}$ Iowans took a leading role in promoting and implementing scrip plans in 1932 and 1933. For a brief moment, the state became a hotbed of alternative currency activism and was heralded by economists, journalists, and politicians from across the United States for its willingness to experiment in the name of recovery. ${ }^{3}$ Following the success of an initial scrip scheme in a small town in Sioux County, such plans proliferated to the point that the Iowa legislature passed a bill facilitating the use of scrip at the county level across the state. Observers flocked to Iowa to see scrip in action. From coast to coast, municipal, county, and even statewide scrip plans were put into operation. By the summer of 1933 , however, the limits of alternative cur-

1. A number of works on alternative currency appeared during the 1930s, including Wayne Weishaar and Wayne W. Parrish, Men Without Money: The Challenge of Barter and Scrip (New York, 1933); and Irving Fisher, Stamp Scrip (New York, 1933). See also Joel W. C. Harper, "Scrip and Other Forms of Local Money" (Ph.D. diss., University of Chicago, 1948).

2. Beyond Iowa, case studies of scrip and local efforts to ameliorate economic conditions during the 1930s include George Tselos, "Self-Help and Sauerkraut: The Organized Unemployed, Inc., of Minneapolis," Minnesota History 45 (1977), 306-20; Loren Gatch, " 'This Is Not United States Currency': Oklahoma's Emergency Scrip Issues during the Banking Crisis of 1933," Chronicles of Oklahoma 82 (2004), 168-99; and Richard H. Harms, "Paid in Scrip," Michigan History 75 (1991), 37-43.

3. Washington Evening Star, 12/9/1932; Washington Post, 5/6/1934; New York Times, 5/6/1934. 
rency as a slump cure were becoming apparent. Even in Iowa, where such plans initially enjoyed tremendous support, criticism grew as scrip failed to live up to its supporters' elevated claims. Despite its eventual failure, the history of scrip illuminates the willingness of ordinary citizens to take action. Within Iowa, scrip was praised for fusing an innovative new idea with older values. It appealed to notions of self-help and individualism; instead of citizens asking for charity or relying on relief, scrip promised to restore dignity to the unemployed by creating jobs and putting currency into their hands once more.

A key component of scrip's appeal was the notion that it would encourage consumers to spend. Americans had enjoyed unprecedented prosperity in the early decades of the twentieth century, and consumer spending was seen as the key to this development. Conversely, when the economic stagnation of the depression arrived, many attributed the crisis to consumers who were foolishly "hoarding" their money rather than spending it. Retailers, politicians, and economists repeatedly exhorted the public to spend now rather than wait until conditions improved. The story of scrip also demonstrates that despite the networks of communication and distribution that linked the nation in the 1930s, many people thought of their participation in the economy in primarily local terms. Supporters of a form of money that was only valid within one town or county envisioned a healthy local economy, where certificates circulated in a closed circle. They ignored the fact that even the smallest communities in the United States were part of a much larger economic system, and that it would be impossible to isolate the local economy from national and international trade.

SCRIP promised to alleviate the shortage of currency in circulation, a problem that crippled the economy during the early 1930s. The stock market crash had been dramatic enough, but a series of bank failures in 1930 and 1931 further shook public confidence. Thousands rushed to withdraw deposits. As banks struggled to maintain liquidity, the money supply contracted dramatically. ${ }^{4}$

4. Richard H. Timberlake, Monetary Policy in the United States: An Intellectual and Institutional History (Chicago, 1993), 266-67. For an account of the banking 
Within Iowa, the lack of cash to perform everyday transactions encouraged some to develop elaborate systems of IOUs, or to exchange goods or services informally. The Des Moines Register set up a Free Swap Bureau where readers could place ads describing surplus items that they wished to trade. H. A. Anderson of Clive happily provided a testimonial about the bureau's effectiveness. He received nine offers for his sunlamp and traded it the second day. Retailers did what they could to extend credit to consumers, or to facilitate barter. One grocery store in Hawarden, Iowa, boasted that it would accept eggs in trade for groceries, "paying more for them than the market warrants us to pay," in an attempt to help area farmers get back on their feet. In Correctionville, just outside of Sioux City, merchants advertised that they would accept corded wood for merchandise. ${ }^{5}$ Such measures were limited in effectiveness, however, and direct trades of merchandise were awkward. Scrip could act as a necessary tool in towns where no funds were available to offer relief (or even to pay city workers). Alternative currency proponents argued that the certificates could serve as a valuable form of credit at a time when banks had failed as sources of loans and municipalities faced shrinking tax revenue.

Scrip had the added benefit of keeping currency within the bounds of a particular community. Throughout the 1920s, independent merchants had waged campaigns to prevent consumers from sending their hard-earned dollars to "outsiders" such as chain stores and mail-order catalogues. As the crisis of the depression deepened, these types of arguments took on a new urgency. Iowa independent merchants repeatedly petitioned the state legislature to restrict chain stores. ${ }^{6}$ Beyond rely-

crisis in Iowa, see Calvin W. Coquillette, "A Failure or 'A Very Great Public Service'? Herbert Hoover, Iowa Banks, and the National Credit Corporation," Annals of Iowa 58 (1999), 388-412.

5. Des Moines Register, 3/22/1933; Hawarden Independent, 3/9/1933; Washington Evening Star, 12/9/1932.

6. See, for example, 1933 Journal of the House of the Forty-Fifth General Assembly, $1 / 18 / 1933,95$. Iowa was not alone in pushing for restrictions on chain stores. See David A. Horowitz, "The Crusade Against Chain Stores: Portland's Independent Merchants, 1928-1935," Oregon Historical Quarterly 89 (1988), 340-68; and Jonathan J. Bean, Beyond the Broker State: Federal Policies toward Small Business, 1936-1961 (Chapel Hill, NC, 1996), 27-32. 
ing on punitive legal measures in their fight against chain stores, retailers across Iowa tried to appeal to the loyalty of local consumers. In Hawarden, area merchants pointed out that although chain stores or retailers in other centers might seem to offer bargain prices, the wise consumer recognized that by patronizing area merchants, "he gets in addition, better schools-better churches-better market facilities-better living conditionsand a better, more prosperous community." 7 In 1931 a group of boosters in Clear Lake took out a series of newspaper ads to trumpet the advantages of spending money locally. Readers were exhorted to "Divide Your Dollars with Your NeighborsBuy at Home." 8 Clear Lake residents who took their dollars to another town or city or sent them to distant mail-order houses were not much better than the soldier who would desert his comrades on the field of battle. ${ }^{9}$

The editor of the Clear Lake Mirror urged support for President Hoover's national anti-hoarding campaign, but added that Clear Lake dwellers had an obligation to place recovery of their own community first.

Above all, buy EVERYTHING POSSIBLE IN THIS TOWN, or from the farmers of our community that will restore our surplus money to working in our own community-among ourselves - and our OWN prosperity will be greater than otherwise. ... When we trade with each other we create local prosperity. When we trade with other people elsewhere who do not spend anything with us, we create local depression. There can be no happy medium - it is either one or the other. ${ }^{10}$

Promoters of local consumption downplayed the extent to which, by the 1930s, and indeed for decades previously, consumers in Clear Lake participated in a much larger economy. No one acknowledged that local merchants sold goods produced not only beyond the borders of Clear Lake or Iowa, but indeed from

\section{Hawarden Independent, 4/16/1931.}

8. Clear Lake Mirror, $7 / 23 / 1931$. This emphasis on localism was not unique to Iowa. For an extended discussion of these types of sales strategies in Buffalo and Rochester, New York, see Sarah Elvins, Sales and Celebrations: Retailing and Regional Identity in Western New York State, 1920-1940 (Athens, OH, 2004).

9. Clear Lake Mirror, 8/6/1931.

10. Clear Lake Mirror, 3/31/1932 (emphasis in original). 
around the world. But pleas to buy locally had an emotional appeal that went beyond a logical examination of the marketplace. In this context, scrip seemed an ideal panacea: it could only be spent within a particular town, and would thus pass "from neighbor to neighbor," concentrating recovery efforts within a tightly controlled area.

IOWA'S INVOLVEMENT in the alternative currency movement began in Hawarden, a town of 3,000 nestled in the northwestern corner of the state. In late summer of 1932, a Dutch immigrant named Charles J. Zylstra became alarmed by the high levels of unemployment in the town and the lack of business for retailers (he himself owned an appliance store). Zylstra was an attractive figure, "sturdy, bronzed, and well over six feet in height," and a youthful 41 years of age. More importantly, he was a forceful and persuasive speaker, possessed of a surprisingly sophisticated understanding of economics. ${ }^{11} \mathrm{He}$ read widely about European experiments with scrip and the monetary theories of German merchant Silvio Gesell. ${ }^{12}$ As a teenager, Zylstra had worked in a cooperative bank formed by his father in Holland before leaving for the United States. He argued that local citizens should not wait in vain for the federal government to inflate the currency or adjust commodity prices. Unemployment was, in his view, "a community problem" that required the cooperation of local people to overcome. Alternative currency would be the answer. Zylstra envisioned using scrip to pay the unemployed to perform a range of improvements in the community such as building bridges, paving roads, and creating sidewalk crossings. Workers would be paid liberally in scrip, as payment of a "bare living wage" would hardly create enough purchasing power to aid retailers and manufacturers. ${ }^{13}$

The distinguishing feature of Zylstra's plan was the use of special stamps to make the scrip self-liquidating. In other words,

11. Weishaar and Parrish, Men Without Money, 19.

12. For information on Gesell and scrip experiments in Schwanenkirchen, Germany, and Woergl, Austria, see Fisher, Stamp Scrip, 17-29; see also Werner Onken, "The Political Economy of Silvio Gesell: A Century of Activism," American Journal of Economics and Sociology 59 (2000), 609-22.

13. Hawarden Independent, 8/4/1932. 
the currency would not be backed by an initial reserve fund of currency from the city treasury. Instead, as the coupons circulated, they would generate revenue for the redemption fund. The front of each certificate proclaimed its $\$ 1$ value, and the back was printed with a grid of 36 squares. Users of the scrip were required to purchase a 3-cent stamp and affix it to one of the squares each time the certificate changed hands. After the money had circulated fully and all 36 squares were filled with stamps, it would be worth $\$ 1.08$ (the extra eight cents would cover administrative and printing costs). Those funds would be deposited with local banks to back the issue, and once a certificate was complete with 36 stamps, it could be redeemed in cash.

Zylstra did not invent stamp scrip, but he was generally heralded as the first American to take seriously the use of alternative currency as a tool to solve the depression. He recalled talking about stamped currency "for years" prior to Hawarden's experiment, but initially thought it would be a government program. Others acknowledged Iowa's role in leading the movement: "Hawarden Shows the Way," trumpeted a hastily published book on the scrip phenomenon in 1933.14

Zylstra acknowledged that some Hawarden residents might be squeamish about departing from the gold standard to use certificates that were not backed by the U.S. Treasury. To overcome local fears about interfering with the "sacred character of money," Zylstra wrote a lengthy column in the Hawarden Independent. There he told the (likely apocryphal) story of a traveling salesman who came to a small town in possession of a $\$ 100$ bill. When leaving his hotel to go on sales calls, the salesman left the bill in the hotel safe. The hotel keeper took the bill, aiming to replace it before the salesman returned, and used it to pay a debt he owed to the grocer. The grocer then passed the bill along to the hardware man in order to settle his account at the store. In this manner the same bill made the rounds of the town, through the hands of the druggist, the coal man, and eventually back into the hands of the hotel keeper. At that point, the traveling

14. Charles Zylstra, Hawarden, to Irving Fisher, New Haven, 12/31/1932, Fisher Papers, New York Public Library (NYPL), reel 1, vol. 29; Weishaar and Parrish, Men Without Money, 18. Irving Fisher, Stamp Scrip, 30, also identified Zylstra as the "originator of Stamp Scrip in America." 
salesman returned, took the bill from the hotel safe, and, to the shock of observers, struck a match and set it on fire. He explained that the bill had been a fake, given to him as a joke by his brother. He wanted to destroy it before it caused any problems. Even though the bill was counterfeit, Zylstra argued, it had done a world of good by circulating through the community: "Just who lost anything by this wiping out of debt?"15 In the same manner, scrip could flow among members of the community who had agreed upon its value. Although it was not backed in the same manner as U.S. currency, it could serve to grease the wheels of business and enable the unemployed to take part in the economy once again.

Zylstra gathered 50 signatures from local businesspeople on a petition in favor of scrip and brought his proposal to the Hawarden City Council. He countered skeptics with carefully reasoned arguments about the effectiveness of his plan. The authors of a book about the scrip movement described how bankers who initially dismissed Zylstra as a "presumptuous rustic" were "repeatedly confounded by his ability to quote and interpret with devastating effect their own figures and authorities." 16

The council approved the plan, and in October 1932 a total of \$300 in scrip certificates was issued to workers on a local improvement project. Each certificate was roughly twice the size of a dollar bill, with printing in red, green, and black on a white background. The unemployed were paid at a rate of 60 cents per day in cash and $\$ 1$ in scrip to work paving a road in town. In theory, if the scrip certificates were fully circulated and stamps were used for each transaction, they would generate $\$ 10,800$ in total business. It was accepted at face value at most Hawarden businesses without opposition. ${ }^{17}$

The plan's most vocal critic was Merle Stone, editor of the Hawarden Independent and an officer of the local bank. Stone's main worry was the possible pooling of certificates in the hands of a few merchants. The men put to work on town improve-

15. Hawarden Independent, 8/4/1932.

16. Weishaar and Parrish, Men Without Money, 19.

17. Harper, "Scrip and Other Forms of Local Money," 157; Christian Science Monitor, 12/21/1932; Hawarden Independent, 10/6/1932; "Iowa Scrip Works So Well Another Issue is Planned," American Banker, 1/23/1933. 
ments would immediately spend their scrip in local stores, but because retailers were unable to use scrip to pay outside suppliers, their options to pass on the certificates were more limited. Merchants would also bear the brunt of costs for the purchase of stamps. "Since the merchant cannot buy goods from wholesalers with the scrip," Stone argued, "they can only use it for wages, for city bills, or pass it to one another for other kinds of goods. I am convinced that the merchant pays as much of the stamp fund as the wage-earner and all others combined." Stone also worried that some unscrupulous dealers might avoid buying the stamps entirely, risking a collapse of the entire project. ${ }^{18}$ The stamps acted as a sort of sales tax for users; if some should decide to simply spend scrip without purchasing stamps, no reserve fund would be created for the eventual redemption of coupons for cash.

Others were more optimistic. Druggist L. H. Fields estimated that less than 10 percent of transactions took place without purchase of the proper stamp, and Mayor B. T. French attributed any failure to carelessness rather than deliberate dishonesty. Merchants proclaimed that the scrip issue was creating new business. Jack D. Boukans, proprietor of an independent clothing store, declared that scrip encouraged people to "buy a few more things than they would ordinarily." Because each coupon was in dollar denominations and no change was given for transactions, people often purchased a few extra items. He noted, "A man who buys a seventy-five cent shirt and offers one dollar in scrip takes the other twenty-five cents in handkerchiefs or socks or something else." 19 Users of scrip were reminded that their participation was essential to the recovery of their community. The back of each certificate stated, "By using this coupon in your transaction you promote employment and an early return to prosperity. Your 3 cent stamp makes this possible." The small price of a stamp seemed a necessary sacrifice to achieve prosperity for all. ${ }^{20}$ Zylstra argued that just as citizens had rallied in the past to support the Liberty and Victory

18. New York Herald Tribune, 2/26/1933, clipping in Fisher Papers, NYPL, reel 1, vol. 29.

19. Weishaar and Parrish, Men Without Money, 24.

20. Christian Science Monitor, 12/21/1932. 
bond drives in wartime, "WE ARE AT WAR NOW, at war with each other. We are trying to hang onto money and property with a deathgrip, but do not seem to realize that it is our friend's throat of which we have hold and the harder we squeeze the more difficult it becomes for this friend to supply us with the necessary food and manufactured articles." 21

Local business leaders were so pleased with the experiment that they sent representatives from the Hawarden Chamber of Commerce to petition Sioux County supervisors to create $\$ 10,000$ in countywide stamp scrip to pay for unemployment relief. Chamber president Sherman French traveled to the county seat to promote Hawarden's plan. Supporters argued that the currency would benefit not only merchants but all residents of the county, including farmers. Scrip spread the burden of paying for relief over everyone "who buys, sells, or performs services," and might even result in the increased consumption of farm products, which would raise prices for farmers. By using selfliquidating coupons to pay for relief rather than borrowing money from the bank, "the county provides a liquid form of credit without obligating itself and without paying interest to anyone." 22 This would create huge savings in future taxes.

HAWARDEN'S EXPERIMENT quickly attracted attention. Delegations from surrounding communities visited to learn more about scrip. Local hotels, restaurants, and retailers enjoyed increased business not only because of their acceptance of scrip, but because of the large numbers of visitors in town. The mayor's office received letters from across the country and around the world asking for details about creating a scrip plan or, in some cases, requesting a sample certificate. The Associated Press ran a story about the use of scrip in Iowa, and specifically mentioned Hawarden's experiment. The American Bankers Association's journal reported on the use of "Make-Believe Money" in Hawarden. The mayor of St. Paul praised the plan, and the finance

21. Charles Zylstra, "Second Release," press release, n.d., Fisher Papers, NYPL, reel 1, vol. 28 (emphasis in original).

22. Sherman Q. French, Hawarden, to Irving Fisher, New Haven, 11/8/1932, Fisher Papers, NYPL, reel 1, vol. 29; Hawarden Independent, 12/15/1932. 
commissioner of Toledo, Ohio, was inspired to develop a scrip plan for his own city. Zylstra copyrighted his plan for stamp scrip, and the Iowa towns of Sigourney, Eldora, Pella, What Cheer, and Nevada all put it into effect. ${ }^{23}$

Zylstra's scheme also gained the notice of Irving Fisher, prominent Yale economist. Fisher was an acknowledged authority not only on matters of monetary reform but also on topics as wide ranging as Prohibition, nutrition, and the League of Nations. He corresponded regularly with both Presidents Hoover and Roosevelt, urging devaluation of the dollar and expansion of the money supply to combat the depression. Fisher was probably the best-known economist in America during this period: his Index Number Institute provided weekly price indices for leading newspapers, and his opinion was regularly sought out in the popular press. His writings reached audiences beyond academia, as he regularly published essays in the Washington Post, New York Herald Tribune, Dallas Times-Herald, and other newspapers, and even wrote a series of bulletins on economic matters for working people that was widely reprinted in the labor press. Fisher gained some notoriety for commenting just prior to the 1929 Crash that stock prices appeared to "have reached what looks like a permanently high plateau." Despite his misplaced optimism, he remained influential in scholarly circles and beyond throughout the 1930s. ${ }^{24}$

While visiting Iowa State College at Ames for a speaking engagement, Fisher learned of Hawarden's experiment and traveled to the town. He met with the mayor, toured stores accepting scrip, and talked to bank officials. Charles Zylstra happened to be out of town on the day of Fisher's visit, but later

23. Don Leafstedt, "Hawarden's 'Scrip' Money," in Hawarden Centennial 18871987: One Hundred Years on the Right Track (Le Mars, 1987), 905-6; Washington Evening Star, 12/9/1932; "Barter and Scrip," American Bankers Association Journal, March 1933, 36; Weishaar and Parrish, Men Without Money, 27-28; Charles Zylstra, Hawarden, to Irving Fisher, New Haven, 12/31/1932, Fisher Papers, NYPL, reel 1, vol. 29.

24. Robert Loring Allen, Irving Fisher: A Biography (Cambridge, MA), 252-53, 190; Michael E. Parrish, Anxious Decades: America in Prosperity and Depression, 1920-1941 (New York, 1992), 232. Robert W. Dimand and John Geanakplos, "Celebrating Irving Fisher: The Legacy of a Great Economist," American Journal of Economics and Sociology 64 (2005), 3-4, argue that Fisher was "the most cited economist in the world" during the early twentieth century. 
wrote to him to explain some of the finer workings of the plan. He argued that scrip was superior to charity: in a time of crisis, the money needed for daily necessities could be collected "as voluntary gifts and donated, destroying people's morale, or it can be provided through a credit extension to provide work." 25 In November 1932, the Christian Science Monitor ran an article about Fisher's praise for the stamp scrip plan, in which Fisher described it as "the most interesting experiment being tried in the United States that I know of to combat the depression." 26

Fisher pointed out one flaw in the Hawarden plan: its requirement of a stamp for every transaction. Instead, he proposed a plan in which the scrip could circulate freely until a stated date (usually every week or two weeks). On that day, a new stamp would have to be purchased by the holder of the scrip. The advantage of dated scrip was that it punished consumers who held onto the money without spending it. In effect, the user would forfeit a negative rate of interest for retaining rather than circulating the money. The only way to avoid paying for a new stamp would be to spend the currency before its "expiry date." The desire to avoid paying for stamps would thus speed the currency through as many hands as possible. By requiring a stamp with every transaction, Fisher argued, the Hawarden plan "would naturally weaken the speed motive and might even reverse it, since it costs 3 cents to transfer the scrip instead of costing 3 cents not to transfer it!" Zylstra countered that requiring a stamp for every transaction appeared more feasible in a smaller community. He argued that bankers might find it difficult to buy and sell scrip if they constantly had to put stamps on all coupons in their possession. ${ }^{27}$

The Yale economist became a missionary for the stamp scrip idea, sending his research assistant Hans Cohrssen to collect material about scrip experiments in Germany and Austria and offering advice about the mechanics of alternative currency plans. He wrote a book, Stamp Scrip, to serve as a handbook for

25. Charles Zylstra, Hawarden, to Irving Fisher, New Haven, 10/28/1932, Fisher Papers, NYPL, reel 1, vol. 29.

26. Christian Science Monitor, 11/11/1932.

27. Fisher, Stamp Scrip, 31; Charles Zylstra, Hawarden, to John Murphy, Mayor, New Haven, 11/18/1932, Fisher Papers, NYPL, reel 1, vol. 29. 
communities hoping to issue scrip; the appendix included a copy of the petition circulated among Hawarden merchants as a model for others to follow. Fisher compared scrip to the bucket of water that sat next to the water pump at his grandmother's country house. From time to time, it would seem that the pump had run dry, for no matter how much one cranked the handle, no water flowed from its spout. At that point, water from the bucket would be added to the open top of the pump; that extra infusion of water would connect with the underground supply and help jerk it to the surface. "Such is the office of Stamp Scrip," Fisher argued, "to prime the pump, which has thus far been unable to connect the great supply of credit currency with the thirsty world. The small scoop of water is the customer walking with his stamp scrip." Fisher and Cohrssen formed the League for Dated Stamp Scrip in order to disseminate "all reliable information bearing upon the many local barter \& scrip exchange movements in America"; they had correspondents in Ohio, California, New York, Georgia, Wisconsin, and Minnesota. By early 1933, members of more than 200 different city councils, chambers of commerce, and business groups across the country had written to Fisher about scrip, and five states, including Iowa, were entertaining scrip bills. 28

Crucial to scrip's success, in Fisher's view, was its ability to put money in the hands of the individual consumer. Stamp scrip went beyond merely facilitating barter or acting as an IOU in a cash-strapped community: it enabled the consumer to take a leading role in currency reflation. Although the president and Congress had taken measures to increase credit, Fisher argued, "unfortunately they have to start at the producer end of the long chain between producer and consumer." Despite the efforts of the Federal Reserve System to increase credit to the banks, many merchants were hesitant to borrow funds until they were sure that consumers were ready to buy. Fisher argued that stamp scrip would "give the consumer the buying power needed to start up operations from the consumer end."

28. Hans Cohrssen, "Working for Irving Fisher," Cato Journal 10 (Winter 1991), 825-33; Fisher, Stamp Scrip, 89, 66; H. R. L. Cohrssen, Executive Director of the League for Dated Stamp Scrip, to Charles Collins, 4/5/1933, Fisher Papers, NYPL, reel 1, vol. 31; Memo, "Re: Stamped Scrip," 1/31/1933, ibid., vol. 28. 
It would generate entirely new transactions, giving a needed boost to the economy. Zylstra, too, emphasized the potential of scrip to encourage consumer spending. In his view, the 3 cents required for a stamp in order to use scrip was a small price to pay to "increase the turnover of commodities tremendously ... enabling everybody in the community to become consumer buyers of luxuries as well as necessities." 29

SUPPORTERS OF SCRIP within Hawarden were confident that the scheme was working. They pointed out that for the first time in more than three years, the number of families applying for relief in Hawarden had decreased. The city clerk reported that 20 fewer families had applied for relief than in the previous year. ${ }^{30}$ It is impossible to determine whether the use of scrip alone caused that decline, but proponents of the scheme were impressed enough to press the city in March 1933 to issue more scrip, this time for the amount of $\$ 1,000$. Encouraged by the success of the Hawarden experiment, other communities in Iowa began to adopt scrip programs between the fall of 1932 and the summer of 1933. At least 14 municipalities-Albia, Boone, Eldora, Nevada, Rock Rapids, Sigourney, Grinnell, Iowa City, Clear Lake, Mason City, Pella, Red Oak, Waterloo, and Traeractually issued some form of scrip, and many others entertained proposals for alternative currency. Polk County used scrip to pay government employees. ${ }^{31}$

Mason City issued $\$ 10,000$ of stamp scrip (fig. 1) and put the unemployed to work on a highway east of the Winnebago River. Several hundred men were paid with scrip for three to six days of work each, crushing rock, quarrying gravel, pouring concrete, and rolling and tamping the road surface. E. H. Wagner, who chaired the project's organizing committee, reminded area residents to readily accept the scrip coupons and purchase 2-cent stamps to affix for each transaction. Instead of objecting to the

29. Irving Fisher, "The Stamped Scrip Plan," reprint from New Republic, 12/21/ 1932, Fisher Papers, NYPL, reel 1, vol. 28; Charles Zylstra, "First Release: Offers Plan to Issue Scrip," press release, n.d., Fisher Papers, NYPL, reel 1, vol. 28. 30. Weishaar and Parrish, Men without Money, 25.

31. Harper, "Scrip and Other Forms of Local Money," 167; Weishaar and Parrish, Men without Money, 29. 


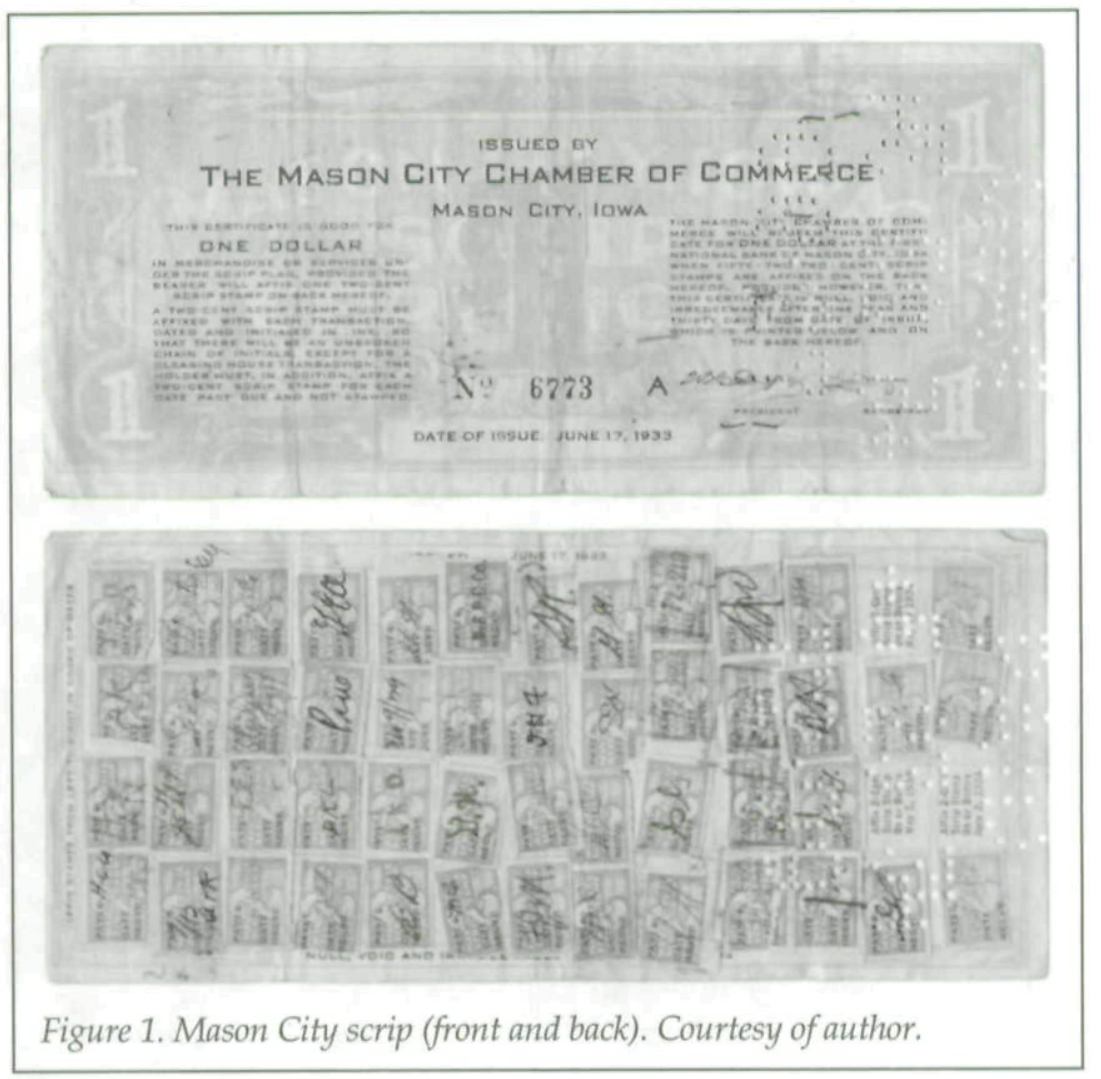

payment of such a small amount, he argued, citizens should "think of the men who worked on that road and of the dependent women and children who were cheered to see the yellow scrip dollars come home-perhaps the first real money which those families had seen for months." Area residents began referring to the highway as "Scrip Road." Years later, local resident Anthony Pavek recalled, "They got a road down here, used to call it Scrip Road ... because they give them scrip money ... that helped them a lot, you know. They could buy groceries and stuff with that." Another area man, G. G. Weida, argued that scrip helped "to keep the wolf away from the door" for poor families. ${ }^{32}$

32. Mason City Globe-Gazette, 6/30/1933; Anthony Pavek, Mason City, interview by Paul Kelso, 11/16/1978, and G. G. Weida, Mason City, interview by Paul Kelso, 11/29/1978, Iowa Labor History Oral Project, Iowa Federation of Labor, AFL-CIO, State Historical Society of Iowa, Iowa City. 
The public was also encouraged to accept scrip as change when making purchases in town, in order to help share the burden of purchasing stamps and hasten the retirement of the issue. Local businesses took out a full-page ad trumpeting, "Let's go Mason City!" and reminded area residents that scrip would bring a half-million dollars in new business to the community. A directory of more than 250 participants in the scrip plan included not only numerous department stores, druggists, grocers, and other retailers, but also four funeral homes, eleven physicians, one billiard hall, two hotels, and seven laundries. Perhaps because the plan enjoyed such widespread support throughout Mason City, even local branches of chain stores joined in and proclaimed that they would accept Mason City scrip "100 Per Cent." J. C. Penney department store, A \& P grocery, and Kresge and Woolworth five-and-ten-cent stores all were listed as full participants in the campaign. The Mason City Globe-Gazette boasted that it would accept scrip as payment for ad space or subscriptions; the scrip drive announcement itself was labeled "Paid for $100 \%$ in Scrip." Big and small outfits were involved: businesses as large as the Consolidated Coal and Coke Company and the Northern Lumber Company were listed next to Smith's Klassy Kleaners and Steve Wilson, Barber. ${ }^{33}$

The adoption of a scrip scheme by a particular community was usually greeted with a flurry of newspaper stories about scrip across Iowa and the rest of the country. Not all scrip schemes within Iowa followed Zylstra's stamp scrip model. In Clear Lake, a group of local businesspeople arranged to buy corn from area farmers using "Corn Money" that could be redeemed at local retailers. On February 24, 1933, eighteen overflowing bins of corn lined Main Street and South Fourth Street in downtown Clear Lake. Farmers were paid 25 cents per bushel (almost three times the market price) and deposited a total of 12,000 bushels of corn for auction by the Corn Exchange Committee. Local Democrats and Republicans vied for public support by making outlandish bids for individual bushels of corn; eventually the Democrats paid $\$ 22.50$ for a bushel to send to Franklin Delano Roosevelt, and the Republicans spent $\$ 33$ for

33. Mason City Globe-Gazette, 6/21/1933, 6/17/1933. 


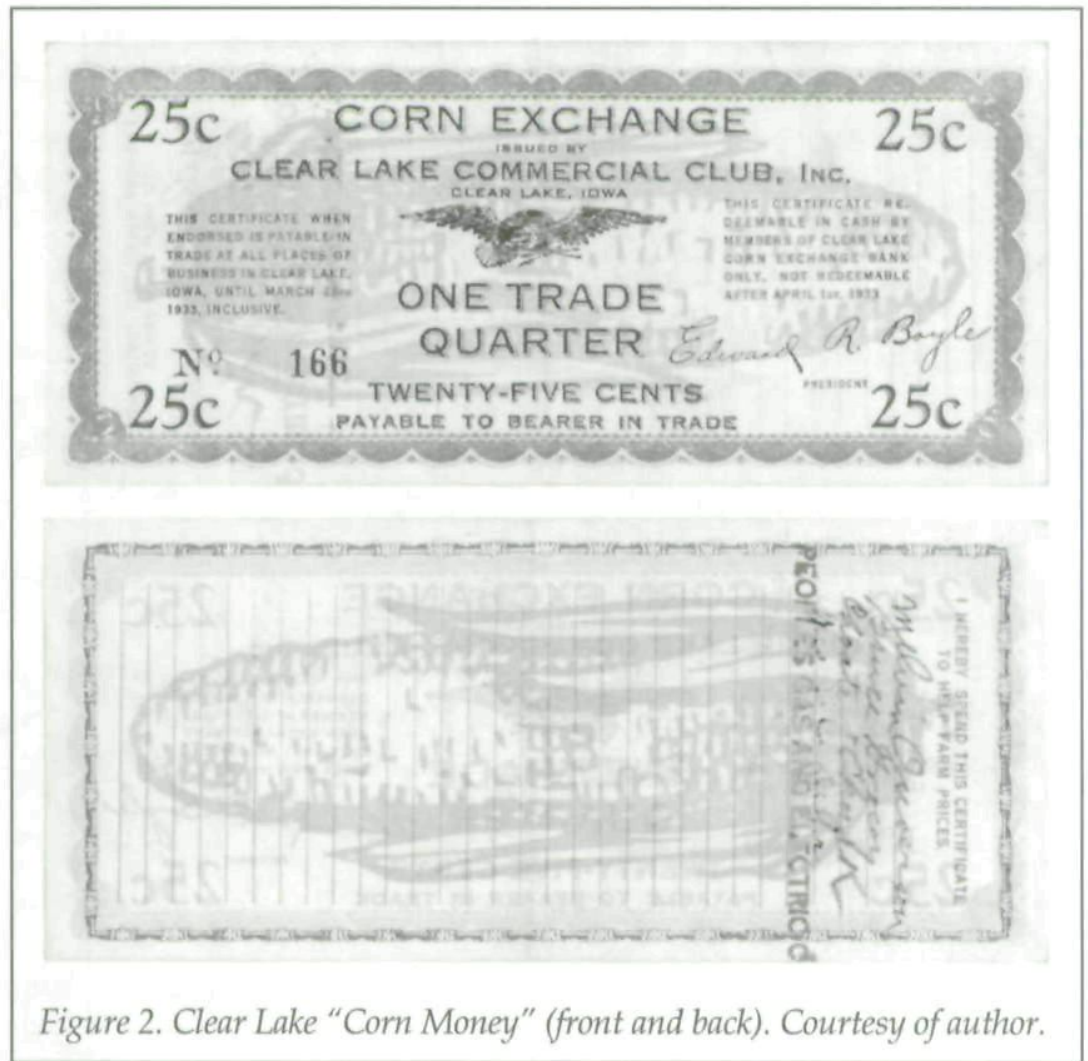

a bushel to send to Herbert Hoover. ${ }^{34} \mathrm{~A}$ total of $\$ 3,000$ of corn scrip was put into circulation. Each certificate featured a drawing of a large ear of corn. Users signed or stamped the back of the coupon under the statement, "I hereby spend this certificate to help farm prices" (fig. 2). Area residents declared that they had abandoned the gold standard for the corn standard. The Corn Exchange Committee sought to extend the benefits of scrip through a "Renovize [sic] With Corn" campaign, in which homeowners were encouraged to hire the unemployed to "remodel, repair, and restore" their houses, and pay for all labor using corn scrip. The local paper argued that using scrip to improve area buildings in this manner was preferable to creating jobs through public works, "because the individual receives the

34. Los Angeles Times, 2/26/1933; Beth Herker, White Clouds, Blue Waters: The Story of Clear Lake (Lake Mills, 1976), 68-69. 
direct benefit of the improvement." The People's Gas and Electric Company of Clear Lake also accepted scrip in payment for utility bills. ${ }^{35}$

Witnessing the spread of scrip across Iowa, Charles Zylstra saw an opportunity for personal advancement. On the basis of his reputation as father of the Hawarden plan, Zylstra entered into state politics in the fall of 1932 . He was named the Democratic candidate for state representative from Sioux County and was elected in a district that had a reputation for being solidly Republican. In early 1933 he made the front page of the Des Moines Sunday Register when he introduced a bill in the legislature empowering Iowa counties to issue stamp scrip as a replacement for tax levies for poor relief. Zylstra proposed that the board of supervisors of any county be permitted to issue scrip upon petition of 10 percent of qualified voters. Adoption of scrip would become mandatory if 30 percent of voters signed the petition. The bill was subject to several hours of debate in the House and was modified so that county supervisors could act to issue scrip upon petition of only 2 percent of the voters. Scrip would become mandatory only if 51 percent of established merchants in a county voted to accept it. ${ }^{36}$

Other politicians threw their support behind Zylstra's initiative. Representative Paul Cunningham of Polk County argued that "if anything will help break the backbone of the depression it is this measure," and Representative Charles Malone of Cass County announced that even if the legislation did not pass, his own county was preparing to put a scrip plan into effect. Cass County employees agreed to take part of their salaries in scrip. The final vote on the bill was a triumph for Zylstra, as 84 voted in favor and only 15 against. Senator Garritt E. Roelofs of Sioux County introduced the companion bill in the Senate, where it passed with only two dissenting votes. In the rush to complete the legislation, the governor signed the bill without any provision for the cost of printing, but it was decided to pass a later corrective act rather than to stop publication of the bill. ${ }^{37}$

35. Mason City Globe-Gazette, 3/2/1933.

36. Des Moines Register, 1/29/1933; Hawarden Independent, 2/2/1933.

37. Hawarden Independent, 2/23/1933, 3/2/1933. 
IOWA'S ENTHUSIASM for scrip seemed particularly well founded when in March 1933 President Roosevelt temporarily closed all of the nation's banks, making it impossible for citizens to withdraw deposits. Across the nation, communities learned to get along without cash, using scrip, barter, and credit to purchase daily necessities. The New York Times featured a photograph of a woman purchasing meat from her butcher in Brooklyn using scrip. In Iowa, reports circulated of the creative use of barter: State Senator O. E. Husted returned to the legislature, bringing with him part of a hog and 12 dozen eggs from his farm in Truro. Husted had less than five dollars in cash on hand when the bank holiday began, and he hoped to swap for coffee, sugar, and other groceries. Des Moines banking officials planned to offer clearinghouse certificates in the amount of 5 percent of bank deposits. While others around the country scrambled to find cash, communities using scrip congratulated themselves for having already put in place a solid mechanism of exchange. F. P. Walker, chair of the Clear Lake Corn Exchange Committee, argued that scrip would be "the salvation of Clear Lake business firms during this nation-wide banking holiday." 38

Irving Fisher's promotional efforts also buoyed support for scrip. While still an advocate of local scrip plans, Fisher set his sights on the creation of a national plan that would benefit from the experiences of towns such as Hawarden. ${ }^{39}$ In Fisher's view, local scrip could help individual towns or counties address unemployment but did little to raise commodity prices and posed problems when retailers made necessary transactions outside the community. National scrip could be made legal tender, which would make participation in scrip plans mandatory for all businesses. Fisher envisioned giving "Prosperity Dollars" in allotments of $\$ 150$ to every unemployed person across the nation. To encourage the speedy circulation of the certificates, Fisher proposed that they would be dated scrip, requiring the purchase of a stamp every Wednesday until the scrip was retired. He advocated a set expiration of the entire scrip program after four years-enough time, in his view, to create sufficient pur-

38. New York Times, 3/12/1933; Des Moines Tribune, 3/7/1933; Mason City Globe-Gazette, 3/4/1933.

39. Christian Science Monitor, 11/28/1932. 
chasing power to end the depression. Because the U.S. Postal Service was part of the federal government, distribution of scrip could take place at post offices, and postage stamps could be used to affix to the back of the certificate. ${ }^{40}$

In order to disperse scrip across the country as quickly as possible, Fisher proposed paying not only the unemployed but also government employees at least in part in scrip wages. Fisher argued that scrip would not interfere with the monetary value of actual U.S. currency. He traveled to Washington to testify before the Committee on Ways and Means of the House of Representatives in May 1933. There he argued that national scrip would not pose a tax burden for the nation, as each certificate would be self-liquidating. The government would collect sufficient revenue from the sale of stamps to fully redeem the money and cover administrative costs. The cost of the stamps would be widely dispersed across the country and spread out over four years, and in any case would be a small price to pay to speed the return to normalcy. Fisher prepared a bill authorizing the Secretary of the Treasury to issue scrip. Senator William Bankhead of Alabama introduced the bill in the Senate, but it was never brought to a vote. 41

Yet as support for scrip across Iowa and the nation grew, new problems arose. It was one thing for scrip to succeed in a town such as Hawarden, with a population of under 3,000 and relatively low levels of unemployment; it was quite another for it to work on a larger scale. In Hawarden, citizens could use scrip to pay for utilities and other major expenses. "In a small city, where everybody knows everybody else," Merle Stone of the Hawarden Independent argued, "scrip will pass in small amounts. They know each other's names and recognize each other's initials" on the cancelled stamps. Stone noted that Hawarden's issue had been very small, and thus had little effect on real money. 42

Hawarden's plan also had enjoyed support from virtually all local businesses, but merchants in other municipalities were

40. "Stamp Scrip as Slump Cure," Literary Digest, 3/11/1933, 8.

41. National Industrial Recovery Administration, "Hearings Before the Committee on Ways and Means," House of Representatives, 73rd Cong., 1st sess., 5/18-20/1933, 168; Harper, "Scrip and Other Forms of Local Money," 92. 42. Weishaar and Parrish, Men Without Money, 27. 
harder to convince. In July 1933 fifty merchants from Council Bluffs challenged Pottawattamie County's plan to issue stamped currency because they were "convinced that the burden of retirement of the scrip would devolve largely upon them." They passed a resolution in the local chamber of commerce refusing to accept scrip in payment for merchandise or on account. Observers wondered if the Zylstra bill had sufficient teeth to compel the participation of merchants in counties where scrip had been authorized, or if the Iowa Supreme Court would have to rule on the matter. ${ }^{43}$

In Des Moines, where scrip was used to provide relief for the unemployed and to pay a portion of the salaries of schoolteachers and county and city employees, the Des Moines Retail Merchants Bureau quickly mobilized against scrip. In a letter to the city council, the bureau argued that scrip was no longer necessary, as Polk County was receiving funds from the Reconstruction Finance Corporation for unemployment relief. Merchants felt that scrip would not be accepted by area manufacturers, insurance companies, railroads, oil companies, and other businesses that performed transactions outside Polk County. More than 50 members of the bureau (including most major department stores) signed an agreement refusing to accept scrip despite the city council's order. In response, Burt Springer of the Home Owned Business Association reported that 1,215 retail stores in Des Moines and Valley Junction had signed the initial petition in favor of scrip and that those stores were still accepting scrip notes in order to "give the unemployed a medium of exchange for merchandise." Not only retailers but other professionals and service providers as well were accepting scrip, with 61 attorneys, 122 physicians and dentists, 37 barber shops, 8 finance companies, 361 grocers, 66 druggists, 59 restaurants, and 46 clothing or shoe stores on the list of participating businesses. Springer remarked that the medical expenses for the delivery of several babies born in Des Moines had been "paid for" in stamp notes, as well as the costs of numerous surgeries. The $\$ 100,000$ of scrip in circulation in Polk County would have to turn over 50 times in order to be

43. Hawarden Independent, 7/27/1933. 
retired, creating "five million dollars worth of labor and merchandise that the community otherwise would not have." 44

By September 1933, however, the city treasurer reported that the plan to retire scrip after each certificate was filled with the appropriate stamps was not working. People were passing scrip without purchasing stamps, and the treasurer's office reported that it had sold only $\$ 7,500$ worth of stamps, although a total of more than $\$ 130,000$ in scrip money had been issued in the county. The chances of the scrip being self-liquidating were slim, as "batches of scrip notes have come back to the county treasurer without having had a single stamp affixed." The certificates were called in by the end of March 1934, and eventually over $\$ 102,000$ in funding bonds had to be sold to retire the scrip. The Tribune's editorial staff acknowledged that the experiment had been a failure despite the high hopes of the county treasurer: "It is a good thing all around to have done with scrip." 45

Across Iowa, enthusiasm for scrip waned. Besides the technical problems with scrip circulation some communities encountered, the appearance of an influx of New Deal money also contributed to a sense that scrip's moment had passed. The Civil Works Administration and Public Works Administration brought federal funding into Iowa communities to create jobs, and this "real money" eliminated the need for scrip. In an extra session during the winter of 1934, the state legislature repealed the Zylstra scrip note law. Hawarden retired its second issue of scrip and made no future plans to use alternative currency. Charles Zylstra threw his hat into the ring in a failed bid for governor in 1934 but faded from public life. He moved to Chicago in 1941 and became a deputy tax collector for the Internal Revenue Service. He died in 1946 at the age of 55. In 1951 Polk County officials proposed burning four barrels of scrip that were taking up too much room in the basement of the courthouse. ${ }^{46}$

44. Des Moines Tribune, 3/28/1933, 5/3/1933, 5/4/1933.

45. Des Moines Tribune, 9/13/1933, 2/28/1934, 9/5/1938, 3/10/1936.

46. New York Times, 5/6/1934; Des Moines Tribune, 4/13/1934; Chicago Daily Tribune, 12/1/1946; clipping from Des Moines Register, 4/8/1951, in Vertical File: Scrip Money, Des Moines Public Library, Central Branch. Zylstra was survived by his widow, Sarah, and six children. His daughters Maryon and Frieda were members of the Chicago Tribune's editorial staff. Maryon Zylstra was known as the paper's "Inquiring Camera Girl." 
IN RETROSPECT, the failure of scrip seems relatively easy to explain. The use of alternative currency might act as a temporary fix in a cash-strapped community, but did not generate sufficient purchasing power to significantly improve economic conditions. Most scrip plans provided employment to a limited number of the jobless (almost exclusively male heads of families). The job creation plans in communities such as Hawarden and Des Moines centered on manual work grading roads or digging ditches-work that was welcomed by many who faced starvation but could hardly be seen as a permanent solution to unemployment. The local nature of scrip, so crucial to its popularity, posed problems as consumers attempted to use scrip to pay for goods brought in from outside the community. Here was the crux of the distinction between a "national" and "local" market: residents of the community understood their participation in the economy in terms of their patronage of the department store on Main Street. That merchant, however, brought in goods from around the nation and even around the globe.

Scrip plans faced other challenges as well: they were complicated to administer and relied on the honesty and goodwill of participants to succeed. In cases when area merchants refused to accept scrip, or when holders of stamp scrip passed it on without purchasing the requisite stamp for each transaction, there was little recourse for the community. Scrip was not legal tender, and no one could be compelled to accept it. It required a high level of effort to keep alternative currency in circulation. B. E. Manley, a resident of Mason City, argued that scrip punished retailers disproportionately: "It was nothing more nor less than a transaction or sales tax, the burden of which was borne very largely by retailers large and small." 47 Stamp scrip plans appeared most successful in smaller communities. Mason City reported that all but 118 pieces of the $\$ 10,000$ in scrip it issued were fully redeemed with stamps on the back, while larger countywide plans did not come close to creating the necessary redemption fund to retire the issue. ${ }^{48}$

47. B. E. Manley, Mason City, letter dated 9/1/1939, quoted in Harper, "Scrip and Other Forms of Local Money," 82.

48. Lester Milligan, Secretary, Mason City Chamber of Commerce, letter dated 8/18/1939, quoted ibid., 81 . 
Given all of these difficulties, we might wonder instead just how scrip managed to have such widespread appeal. For a brief moment, it was hailed by economists, politicians, and laypeople as the "magic solution" to the depression. The idea that a simple plan could transform the economy appealed at a time when many Americans felt swept up in economic forces beyond their control. An editorial cartoon in the Clear Lake Mirror in November 1931 showed a frustrated man looking for a needle in a haystack, but reassured readers, "We will sooner or later find the Majic [sic] key to a new era of greater prosperity than ever." 49 The average citizen knew little about currency reflation, but scrip seemed an understandable, even practical, way for individuals to take charge of their economic fate. The perception of scrip as innovative and experimental only added to its attraction. Joel Harper argues in his study of local money that "the novelty of scrip itself appealed to many persons at a time when a reduced volume of business gave them leisure to ponder the intricacies of monetary theory and at the same time provided an immediate and personal incentive for a search for depression remedies." 50 Merle Stone of Hawarden, one of the town's most vocal critics of scrip, conceded that it had a "strong imaginative appeal." He noted that interest in scrip as a depression solution went "up like a rocket," but experience demonstrated that it was "pretty much of a 'dud.'" 51

Even after some scrip programs proved less than successful, the appeal of alternative currency plans did not die out completely. When Upton Sinclair ran for governor of California on the Democratic ticket in 1934, he included a plan for scrip in his End Poverty in California (EPIC) campaign. American newspapers reported with interest the scrip initiative of the Canadian province of Alberta, which issued "prosperity certificates" in 1936 to civil servants and men employed on public works projects. ${ }^{52}$ Dr. Francis Townsend proposed a "Prosperity Plan" that relied on scrip "velocity dollars" to provide pensions for

49. Clear Lake Mirror, 11/5/1931.

50. Harper, "Scrip and Other Forms of Local Money," 40.

51. Hawarden Independent, 5/11/1933.

52. New York Times, 7/12/1936. 
senior citizens who promised to spend the money within 30 days. ${ }^{53}$ California's Ham and Eggs Movement proposed giving $\$ 30$ every Thursday in scrip to state residents over the age of 50 in order to stimulate the economy. Despite the vocal opposition of the editorial board of the Los Angeles Times, the Credit Bureaus of California, and the California Retailers Association, thousands signed petitions to amend the state constitution to allow the scrip pension plan, and well over a million voted in favor of it in a 1939 referendum. ${ }^{54}$

The story of scrip is a curious one. Support for alternative currency united a range of disparate figures, from Charles Zylstra of the small town of Hawarden to Irving Fisher at Yale. Attitudes towards scrip were not always predictable. In some communities, merchants led the call for issuing new currency, while in others they opposed it. Government employees might embrace scrip as a needed stopgap, or reject it when faced with the prospect of receiving a salary in scrip. Fascination with "funny money" brought journalists and politicians to communities that had implemented scrip plans. Scrip was the focus of debates in the town halls of Iowa and eventually in the state legislature. Its promoters often oversold its potential as a panacea, the "way out" of an unprecedented national and international crisis.

Yet exploration of this story is crucial to our understanding of Americans' response to the Great Depression, and illuminates the experiences of Iowans in particular during the early 1930s. Supporters of scrip drew on traditional notions of voluntarism, self-help, and community activism to win support for their unorthodox plan. In the face of financial crisis, many Iowans hoped to take control of their financial destiny, and displayed a remarkable sense of initiative and a willingness to experiment that attracted notice from around the nation.

53. New York Times, 4/30/1937. Irving Fisher condemned Townsend's plan, which would give money to senior citizens by taking away the purchasing power of others through taxes. New York Times, 1/13/1936.

54. Los Angeles Times, 9/15/1933, 7/30/1936, 10/5/1939, 9/26/1938; Washington Post, 7/31/1936; V. F. Coe, "Dated Stamp Scrip in Alberta," Canadian Journal of Economics and Political Science 4 (1938), 60-91. 
Copyright of Annals of Iowa is the property of State of Iowa, by \& through the State Historical Society of Iowa and its content may not be copied or emailed to multiple sites or posted to a listserv without the copyright holder's express written permission. However, users may print, download, or email articles for individual use. 